\title{
Flavobacterium fryxellicola sp. nov. and Flavobacterium psychrolimnae sp. nov., novel psychrophilic bacteria isolated from microbial mats in Antarctic lakes
}

\author{
Stefanie Van Trappen, Ilse Vandecandelaere, Joris Mergaert \\ and Jean Swings
}

Correspondence Stefanie Van Trappen stefanie.vantrappen@UGent.be

\begin{abstract}
Laboratorium voor Microbiologie, Vakgroep Biochemie, Fysiologie en Microbiologie, Universiteit Gent, K. L. Ledeganckstraat 35, B-9000 Gent, Belgium
\end{abstract}

\begin{abstract}
Taxonomic studies were performed on seven strains isolated from microbial mats in Antarctic lakes of the McMurdo Dry Valleys. Phylogenetic analysis based on 16S rRNA gene sequences indicated that these strains are related to the genus Flavobacterium; sequence similarity values with their nearest phylogenetic neighbours ranged from $97 \cdot 0$ to $98 \cdot 7 \%$. Results of DNA-DNA hybridization and comparison of repetitive extragenic palindromic DNA-PCR fingerprinting patterns revealed that these strains are members of two distinct species. Genotypic results, together with phenotypic characteristics, allowed these species to be differentiated from related recognized Flavobacterium species. The isolates are psychrophilic, Gram-negative, chemoheterotrophic, rod-shaped cells. Their whole-cell fatty acid profiles are similar and include $\mathrm{C}_{15: 0}, \mathrm{C}_{15: 0}$ anteiso, $\mathrm{C}_{15: 0}$ iso, $\mathrm{C}_{15: 1} \omega 6 c, \mathrm{C}_{16: 0}$ iso, $\mathrm{C}_{16: 0}$ iso 3-OH, $\mathrm{C}_{16: 1}$ iso and summed feature 3 (which comprises $\mathrm{C}_{15: 0}$ iso $2-\mathrm{OH}$ and/or $\mathrm{C}_{16: 1} \omega 7 \mathrm{c}$ ) as the major fatty acid components. On the basis of these results, two novel species are proposed: Flavobacterium fryxellicola sp. nov., consisting of three strains with LMG $22022^{\top}\left(=\mathrm{CIP} 108325^{\top}\right)$ as the type strain; and Flavobacterium psychrolimnae sp. nov., consisting of four strains with LMG $22018^{\top}$ (=CIP $108326^{\top}$ ) as the type strain. DNA G $+C$ contents of $F$. fryxellicola and F. psychrolimnae are $35 \cdot 2-35 \cdot 9$ and $33 \cdot 8-34 \cdot 5$ mol\%, respectively.
\end{abstract}

Members of the phylum Bacteroidetes are abundant in freshwater and marine ecosystems and these bacteria may have a specialized role in the uptake and degradation of organic matter in cold, aquatic environments (Kirchman, 2002). Several novel species, added to the genus Flavobacterium since 1996, have originated from Antarctic habitats (Van Trappen et al., 2003, 2004; and references cited therein).

During the MICROMAT project (November 1998February 2001), 746 bacterial strains were isolated under

Published online ahead of print on 14 January 2005 as DOI 10.1099/ ijs.0.03056-0.

Abbreviation: rep-PCR, repetitive extragenic palindromic DNA-PCR.

The GenBank/EMBL/DDBJ accession numbers for the 16S rRNA gene sequences of strains LMG 22018', LMG 22022', LMG 22020, R-9010 and R-7518 are AJ585428, AJ811961, AJ585427, AJ601392 and AJ601393, respectively.

Figures showing a rep-PCR profile and a phylogenetic tree, and tables giving the sources of strains, fatty acid composition data and phenotypic characteristics are available as supplementary material in IJSEM Online. heterotrophic conditions from microbial mat samples that were collected from ten Antarctic lakes (Van Trappen et al., 2002). Numerical analysis of the fatty acid composition of the isolates and 16S rRNA gene sequence analysis, performed on representative strains, showed that the diversity of heterotrophic bacteria in microbial mats from Antarctic lakes is very high. Moreover, many fatty acid clusters were shown to contain multiple taxa when tested by repetitive extragenic palindromic DNA-PCR (rep-PCR) fingerprinting, a technique used to investigate the genomic diversity of each fatty acid cluster in more detail (Van Trappen et al., $2003,2004)$. Several strains belonging to fatty acid clusters 5, 6 and 10 have previously been described as novel Flavobacterium species: Flavobacterium gelidilacus, Flavobacterium degerlachei, Flavobacterium frigoris and Flavobacterium micromati (Van Trappen et al., 2003, 2004).

In the present work, the taxonomic relationships of 22 strains from fatty acid cluster 5 (as delineated by Van Trappen et al., 2002) were studied. A group of 11 of these strains was identified as Flavobacterium xanthum, whereas another rep-cluster of four strains was identified as the recently described species F. frigoris (Van Trappen 
et al., 2004), based on 16S rRNA gene sequence analysis (see Fig. A, available as supplementary material in IJSEM Online) and DNA-DNA hybridizations (S. Van Trappen, unpublished results). These strains were not investigated further and are listed in Table A (available as supplementary material in IJSEM Online). Seven strains, listed in Table B (available as supplementary material in IJSEM Online), proved to belong to new taxa, and were further studied by polyphasic taxonomic analysis.

Unless otherwise mentioned, strains were cultivated routinely on R2A medium (Difco) at $20^{\circ} \mathrm{C}$ for $48 \mathrm{~h}$, except for Flavobacterium pectinovorum LMG $4031^{\mathrm{T}}$ and Flavobacterium saccharophilum LMG $8384^{\mathrm{T}}$, which were cultivated on TSA medium (BBL) at $20^{\circ} \mathrm{C}$ for $48 \mathrm{~h}$, and Flavobacterium xinjiangense LMG $21985^{\mathrm{T}}$ and Flavobacterium omnivorum LMG $21986^{\mathrm{T}}$, which were cultivated on $\mathrm{R} 2 \mathrm{~A}$ medium at $11^{\circ} \mathrm{C}$ for 5 days.

DNA was prepared according to the method of Pitcher et al. (1989) and rep-PCR fingerprinting (based on primers targeting the repetitive extragenic palindromic sequence) was performed on all strains of FAA cluster 5 (75 strains) of Van Trappen et al. (2002) using the primer $\mathrm{GTG}_{5}$ (Versalovic et al., 1991), as described previously (Van Trappen et al., 2003). Seven of these strains, listed in Table B, could be divided into two different clusters according to their profile type (see Fig. B, available as supplementary material in IJSEM Online) and numerical analysis was carried out using the BIONUMERICS software package (Applied Maths), as described by the same authors. These clusters are hereafter referred to as rep-PCR profile type I (comprising three strains) and type II (with four strains) (see Table B).

Almost-complete 16S rRNA gene sequences (1466-1479 nt) of strains LMG $22022^{\mathrm{T}}$, LMG $22018^{\mathrm{T}}$, LMG 22020, R-9010 and R-7518 were determined as described previously (Van Trappen et al., 2004). The most closely related sequences were found using the program FASTA; sequences from reference strains were aligned, and editing of the alignment and reformatting was performed with the programs BIOEDIT (Hall, 1999) and FORCON (Raes \& Van de Peer, 1999). Evolutionary distances were calculated by using the Jukes-Cantor evolutionary model and a phylogenetic tree (Fig. A, available as supplementary material in IJSEM Online) was constructed by using the neighbour-joining method (Saitou \& Nei, 1987) with the program TREECON (Van de Peer \& De Wachter, 1994).

The seven novel Antarctic strains form two distinct branches within the genus Flavobacterium, supported by high bootstrap values, and they belong to a clade of the phylogenetic tree which consists almost exclusively of recently described Flavobacterium species from cold environments, such as Flavobacterium gillisiae, F. degerlachei, F. frigoris, F. xinjiangense, F. xanthum, F. omnivorum, Flavobacterium frigidarium, F. gelidilacus, Flavobacterium limicola, Flavobacterium tegetincola and F. micromati. Other psychrophilic Flavobacterium species, such as Flavobacterium hibernum and Flavobacterium psychrophilum, do not belong to this clade and form separate branches.

The 16S rRNA gene sequence of the representative strain of rep-PCR profile type I (LMG $22022^{\mathrm{T}}$ ) showed $98 \cdot 5 \%$ similarity to $F$. omnivorum, $98 \cdot 1 \%$ to $F$. frigidarium, $97 \cdot 7 \%$ to $F$. xinjiangense, $97.6 \%$ to $F$. limicola, $97 \cdot 5 \%$ to $F$. micromati, $97 \cdot 4 \%$ to F. xanthum and less than $97 \cdot 4 \%$ to other Flavobacterium species. A FASTA search indicated that the highest similarity for the LMG $22022^{\mathrm{T}}$ sequence is 99.9\% with 'Flavobacterium aff. xylanivorum' A1/C-aer/ OIV (GenBank/EMBL/DDBJ accession no. AJ297440), which was also isolated from a microbial mat from Lake Fryxell. Sequences of the representative strains of rep-PCR profile type II (LMG $22018^{\mathrm{T}}$ and LMG 22020) are identical and showed a sequence similarity of $98.7 \%$ to F. limicola, $98 \cdot 4 \%$ to $F$. omnivorum, $97 \cdot 9 \%$ to $F$. xinjiangense, $97 \cdot 7 \%$ to $F$. degerlachei, $97 \cdot 6 \%$ to $F$. frigoris, $97 \cdot 5 \%$ to $F$. gillisiae and $97 \cdot 3 \%$ to F. xanthum and less than $97 \cdot 0 \%$ to other Flavobacterium species. Sequences of strains LMG $22018^{\mathrm{T}}$ and LMG $22022^{\mathrm{T}}$ showed a sequence similarity of $98 \cdot 0 \%$ to each other.

Genomic relatedness between the novel Antarctic strains (representing the two different rep-PCR profile types and their most closely related phylogenetic neighbours) was determined by DNA-DNA hybridizations. DNA-DNA hybridizations were carried out with photobiotin-labelled probes in microplate wells as described by Ezaki et al. (1989), using an HTS7000 BioAssay reader (Perkin Elmer) for the fluorescence measurements. The hybridization temperature was $30^{\circ} \mathrm{C}$ and reciprocal experiments were performed for every pair of strains. Differences between reciprocal experiments were less than $11 \%$. The hybridization level between strains LMG $22022^{\mathrm{T}}$, LMG 22023 and LMG 22024 of rep-PCR profile type I was $79 \cdot 0-93 \cdot 3 \%$, indicating that these three strains belong to a single species (Wayne et al., 1987). Hybridization values of LMG $22022^{\mathrm{T}}$ with its nearest phylogenetic neighbours ( $F$. omnivorum LMG $21986^{\mathrm{T}}, F$. frigidarium LMG $21010^{\mathrm{T}}$ and $F$. xinjiangense $\mathrm{LMG} 21985^{\mathrm{T}}$ ) were in the range of $16-54 \%$ and the hybridization level between strains LMG $22018^{\mathrm{T}}$ and LMG $22022^{\mathrm{T}}$ was also low, with a mean value of $34 \%$. These results indicate that the strains from rep-PCR profile type I represent a novel Flavobacterium species, for which the name Flavobacterium fryxellicola sp. nov. is proposed. Hybridization results between strains LMG $22018^{\mathrm{T}}$ and LMG 22020 of rep-PCR profile type II $(96.5 \%)$ showed that the strains of rep-PCR profile type II belong to a single species. It is now well established that similar rep-PCR profiles correlate with high genomic DNA-DNA hybridization values (Versalovic et al., 1994; Rademaker \& De Bruijn, 1997; Rademaker et al., 2000; Van Trappen et al., 2003, 2004). The low hybridization level $(21 \cdot 9-48 \cdot 8 \%)$ between LMG $22018^{\mathrm{T}}$ and its nearest phylogenetic neighbours (F. limicola LMG $21930^{\mathrm{T}}$, F. omnivorum LMG $21986^{\mathrm{T}}, F$. xinjiangense LMG $21985^{\mathrm{T}}$, F. degerlachei LMG $21915^{\mathrm{T}}, F$. frigoris LMG $21922^{\mathrm{T}}$, 
F. gillisiae LMG $21422^{\mathrm{T}}$ and F. xanthum LMG $8372^{\mathrm{T}}$ ) revealed that the four strains of rep-PCR profile type II constitute a novel species, for which the name Flavobacterium psychrolimnae sp. nov. is proposed. These results clearly show that the novel Antarctic isolates are genotypically distinct from related Flavobacterium species, although the novel isolates share more than $97 \%$ (up to $98.7 \%$ ) $16 \mathrm{~S}$ rRNA gene sequence similarity with their closest phylogenetic neighbours.

DNA $G+C$ contents of the Antarctic strains were determined using an HPLC method, as described by Van Trappen et al. (2003). The DNA G $+C$ contents of $F$. fryxellicola strains LMG $22022^{\mathrm{T}}$, LMG 22023 and LMG 22024 are 35.2, 35.9 and $35.5 \mathrm{~mol} \%$, respectively; those of $F$. psychrolimnae strains LMG 22018 ${ }^{\mathrm{T}}$, LMG 22019, LMG 22020 and LMG 22021 are $34 \cdot 5,33 \cdot 9,34 \cdot 1$ and $33 \cdot 8 \mathrm{~mol} \%$, respectively. These values are consistent with $\mathrm{G}+\mathrm{C}$ contents of the genus Flavobacterium, which range from 30 to $37 \mathrm{~mol} \%$ (Bernardet et al., 1996; Van Trappen et al., 2003).

Cellular fatty acid patterns of the Antarctic strains are based on data generated by Van Trappen et al. (2002) and are very similar (see Table $\mathrm{C}$, available as supplementary material in IJSEM Online). The major constituents include $\mathrm{C}_{15: 0}, \mathrm{C}_{15: 0}$ iso, $\mathrm{C}_{15: 1} \omega 6 c, \mathrm{C}_{16: 0}$ iso $3-\mathrm{OH}$ and summed feature 3 (which comprises $\mathrm{C}_{15: 0}$ iso 2-OH and/or $\left.\mathrm{C}_{16: 1} \omega 7 c\right)$. Hydroxylated fatty acids and iso- and anteisobranched fatty acids were present as minor components. Strains of $F$. psychrolimnae also possessed relatively large amounts of $\mathrm{C}_{16: 0}$ iso. The fatty acid profiles resemble those determined for other Flavobacterium species (Bernardet et al., 1996).

Morphological, physiological and biochemical tests were performed as described previously (Van Trappen et al., 2003). The strains show the typical morphological characteristics of Flavobacterium species (Bernardet et al., 2002). Their physiological and biochemical characteristics are given in the species descriptions. F. fryxellicola and $F$. psychrolimnae can be clearly differentiated from each other and related Flavobacterium species by several phenotypic characteristics (see Table D, available as supplementary material in IJSEM Online); Flavobacterium species not given in the table also differ from these novel species.

\section{Description of Flavobacterium fryxellicola sp. nov.}

Flavobacterium fryxellicola [fry.xel.li' co.la. N.L. n. Fryxellum (or Fryxellus) Lake Fryxell; L. suffix -cola an inhabitant; N.L. n. fryxellicola inhabitant of Lake Fryxell].

Cells are Gram-negative, short rods $(1 \cdot 0-1 \cdot 5 \times 3 \cdot 0-4 \cdot 0 \mu \mathrm{m})$ that often form short chains. Gliding motility is not observed. Grows at $5-25^{\circ} \mathrm{C}$, with optimal growth at $20^{\circ} \mathrm{C}$; no growth occurs at $30^{\circ} \mathrm{C}$. Yellow-orange, convex, translucent colonies with entire margins and a diameter of $1-$ $3 \mathrm{~mm}$ are formed on R2A plates after 6 days incubation.
Colonies on agar of Anacker \& Ordal (1955) are flat, round with entire margins and $0.5-1.0 \mathrm{~mm}$ in diameter after 14 days incubation. Growth also occurs on trypticase soy agar (weak growth) and nutrient agar; no growth is observed on marine agar. Colonies do not adhere to the agar. Growth occurs in $0-2 \% \mathrm{NaCl}$, but not in $5-10 \%$ $\mathrm{NaCl}$. Aesculin is degraded. Catalase and oxidase tests are positive. Growth is observed (API 20NE) on glucose and maltose, whereas no growth is detected on arabinose, mannitol, mannose, $\mathrm{N}$-acetylglucosamine, gluconate, caprate, adipate, malate, citrate or phenylacetate. Acids are not produced from carbohydrates (API 20E). Agar, alginate, pectin, chitin, casein, carboxymethyl-cellulose, DNA, gelatin, starch, tyrosine and urea are not degraded. Congo red is not absorbed and no flexirubin-type pigments are present. Brown diffusible pigment is not produced on L-tyrosine agar and no precipitate is formed on egg-yolk agar. Tests for indole production, citrate utilization, nitrate reduction and hydrogen sulfide production are negative. Voges-Proskauer reaction is positive for all strains. None of the strains has arginine dihydrolase, lysine decarboxylase, ornithine decarboxylase, tryptophan deaminase (API 20E), lipase (C14), $\alpha$-chymotrypsin, trypsin, $\beta$-galactosidase, $\beta$ glucuronidase, $\beta$-glucosidase, $N$-acetyl- $\beta$-glucosaminidase, $\alpha$-mannosidase or $\alpha$-fucosidase (API ZYM) activities. Weak enzymic activity is observed for esterase lipase (C8), cystine arylamidase and $\alpha$-galactosidase, medium activity is observed for esterase (C4) and $\alpha$-glucosidase, and strong activity is observed for alkaline phosphatase, leucine arylamidase, valine arylamidase, acid phosphatase and naphthol-AS-BI-phosphohydrolase (API ZYM). Cells contain the fatty acids $\mathrm{C}_{15: 0}, \mathrm{C}_{15: 0}$ iso, $\mathrm{C}_{15: 1} \omega 6 c, \mathrm{C}_{16: 0}$ iso, $\mathrm{C}_{16: 0}$ iso 3-OH and summed feature 3 (which comprises $\mathrm{C}_{15: 0}$ iso 2-OH and/or $\mathrm{C}_{16: 1} \omega 7 c$ ) as the main constituents. DNA G $+\mathrm{C}$ content is $35 \cdot 2-35 \cdot 9 \mathrm{~mol} \%$. Isolated from microbial mats from Lake Fryxell (fresh/brackish) in the McMurdo Dry Valleys, Antarctica.

The type strain is LMG $22022^{\mathrm{T}}\left(=\mathrm{CIP} 108325^{\mathrm{T}}\right)$.

\section{Description of Flavobacterium psychrolimnae sp. nov.}

Flavobacterium psychrolimnae (psy.chro'lim.nae. Gr. adj. psychros cold; Gr. fem. n. limna lake; N.L. gen. n. psychrolimnae of the cold lake).

Cells are Gram-negative, short rods $(0.5 \times 2 \cdot 0 \mu \mathrm{m})$. Gliding motility is not observed. Grows at $5-25^{\circ} \mathrm{C}$, with optimal growth at $20^{\circ} \mathrm{C}$; weak growth is observed at $30^{\circ} \mathrm{C}$ and no growth occurs at $37^{\circ} \mathrm{C}$. Yellow, convex, translucent colonies with entire margins and a diameter of $1-3 \mathrm{~mm}$ are formed on R2A plates after 6 days incubation. Colonies on agar of Anacker \& Ordal (1955) are flat, round with entire margins and $0.5-1.0 \mathrm{~mm}$ in diameter after 14 days incubation. Growth also occurs on trypticase soy agar and nutrient agar; no growth is detected on marine agar. Colonies do not adhere to the agar. Growth occurs in $0-2 \% \mathrm{NaCl}$, but not in $5-10 \% \mathrm{NaCl}$. Aesculin, casein 
and starch are degraded. Catalase and oxidase tests are positive. Growth is observed (API 20NE) on glucose, mannose and maltose, whereas no growth is detected on arabinose, mannitol, $\mathrm{N}$-acetylglucosamine, gluconate, caprate, adipate, malate, citrate or phenylacetate. Acids are not produced from carbohydrates (API 20E). Agar, alginate, pectin, chitin, carboxymethyl-cellulose, DNA, gelatin, tyrosine and urea are not degraded. Congo red is not absorbed and no flexirubin-type pigments are present. Brown diffusible pigment is not produced on L-tyrosine agar and no precipitate is formed on egg-yolk agar. Tests for indole production, citrate utilization, nitrate reduction, VogesProskauer reaction and hydrogen sulfide production are negative. None of the strains has arginine dihydrolase, lysine decarboxylase, ornithine decarboxylase, tryptophan deaminase (API 20E) and lipase (C14), $\alpha$-galactosidase, $\beta$-galactosidase, $\beta$-glucuronidase, $\alpha$-mannosidase or $\alpha$ fucosidase (API ZYM) activities. Weak enzymic activity is observed for esterase (C4), esterase lipase (C8), cystine arylamidase, $\alpha$-chymotrypsin, trypsin and $\beta$-glucosidase, medium activity is observed for $N$-acetyl- $\beta$-glucosaminidase, acid phosphatase, $\alpha$-glucosidase and naphthol-AS-BIphosphohydrolase, and strong activity is observed for alkaline phosphatase, leucine arylamidase and valine arylamidase (API ZYM). Cells contain the fatty acids $\mathrm{C}_{15: 0}, \mathrm{C}_{15: 0}$ iso, $\mathrm{C}_{15: 1} \omega 6 c, \mathrm{C}_{16: 0}$ iso, $\mathrm{C}_{16: 0}$ iso 3-OH, $\mathrm{C}_{16: 1}$ iso and summed feature $3\left(\mathrm{C}_{15: 0}\right.$ iso $2-\mathrm{OH}$ and/or $\left.\mathrm{C}_{16: 1} \omega 7 \mathrm{c}\right)$ as the main constituents. DNA G+C content is $33 \cdot 8-$ $34.5 \mathrm{~mol} \%$. Isolated from microbial mats from the freshwater lakes Fryxell (fresh/brackish) and Hoare in the McMurdo Dry Valleys, Antarctica.

The type strain is LMG $22018^{\mathrm{T}}$ ( $=$ CIP $108326^{\mathrm{T}}$ ).

\section{Acknowledgements}

This work was funded by the Bijzonder Onderzoeksfonds (BOF), Universiteit Gent, Belgium. Part of this work was conducted in the framework of the MICROMAT project 'Biodiversity of microbial mats in Antarctica' (project no. BIO4980040), funded by the European Commission under the Biotech Programme.

\section{References}

Anacker, R. L. \& Ordal, E. J. (1955). Study of a bacteriophage infecting the myxobacterium Chondrococcus columnaris. J Bacteriol 70, 738-741.

Bernardet, J.-F., Segers, P., Vancanneyt, M., Berthe, F., Kersters, K. \& Vandamme, P. (1996). Cutting a Gordian knot: emended classification and description of the genus Flavobacterium, emended description of the family Flavobacteriaceae, and proposal of Flavobacterium hydatis nom. nov. (basonym, Cytophaga aquatilis Strohl and Tait 1978). Int J Syst Bacteriol 46, 128-148.

Bernardet, J.-F., Nakagawa, Y. \& Holmes, B. (2002). Proposed minimal standards for describing new taxa of the family Flavobacteriaceae and emended description of the family. Int J Syst Evol Microbiol 52, 1049-1070.

Ezaki, T., Hashimoto, Y. \& Yabuuchi, E. (1989). Fluorometric deoxyribonucleic acid-deoxyribonucleic acid hybridization in microdilution wells as an alternative to membrane filter hybridization in which radioisotopes are used to determine genetic relatedness among bacterial strains. Int J Syst Bacteriol 39, 224-229.

Hall, T. A. (1999). BIOEDIT: a user-friendly biological sequence alignment editor and analysis program for Windows 95/98/NT. Nucleic Acids Symp Ser 41, 95-98.

Humphry, D. R., George, A., Black, G. W. \& Cummings, S. P. (2001). Flavobacterium frigidarium sp. nov., an aerobic, psychrophilic, xylanolytic and laminarinolytic bacterium from Antarctica. Int J Syst Evol Microbiol 51, 1235-1243.

Kirchman, D. L. (2002). The ecology of Cytophaga-Flavobacteria in aquatic environments. FEMS Microbiol Ecol 39, 91-100.

Pitcher, D. G., Saunders, N. A. \& Owen, R. J. (1989). Rapid extraction of bacterial genomic DNA with guanidium thiocyanate. Lett Appl Microbiol 8, 151-156.

Rademaker, J. L. W. \& de Bruijn, F. J. (1997). Characterization and classification of microbes by rep-PCR genomic fingerprinting and computer assisted pattern analysis. In DNA Markers: Protocols, Applications and Overviews, pp. 151-171. Edited by G. CaetanoAnollés \& P. M. Gresshoff. New York: Wiley.

Rademaker, J. L. W., Hoste, B., Louws, F. J., Kersters, K., Swings, J., Vauterin, L., Vauterin, P. \& de Bruijn, F. J. (2000). Comparison of AFLP and rep-PCR genomic fingerprinting with DNA-DNA homology studies: Xanthomonas as a model system. Int J Syst Evol Microbiol 50, 665-677.

Raes, J. \& Van de Peer, Y. (1999). ForCon: a software tool for the conversion of sequence alignments (http://www.ebi.ac.uk/embnet. news/vol6_1/ForCon/body_forcon.html).

Saitou, N. \& Nei, M. (1987). The neighbor-joining method: a new method for reconstructing phylogenetic trees. Mol Biol Evol 4, 406-425.

Tamaki, H., Hanada, S., Kamagata, Y., Nakamura, K., Nomura, N., Nakano, K. \& Matsumura, M. (2003). Flavobacterium limicola sp. nov., a psychrophilic, organic-polymer-degrading bacterium isolated from freshwater sediments. Int J Syst Evol Microbiol 53, 519-526.

Van de Peer, Y. \& De Wachter, R. (1994). TREECON for Windows: a software package for the construction and drawing of evolutionary trees for the Microsoft Windows environment. Comput Appl Biosci 10, 569-570.

Van Trappen, S., Mergaert, J., Van Eygen, S., Dawyndt, P., Cnockaert, M. C. \& Swings, J. (2002). Diversity of 746 heterotrophic bacteria isolated from microbial mats from ten Antarctic lakes. Syst Appl Microbiol 25, 603-610.

Van Trappen, S., Mergaert, J. \& Swings, J. (2003). Flavobacterium gelidilacus sp. nov., isolated from microbial mats in Antarctic lakes. Int J Syst Evol Microbiol 53, 1241-1245.

Van Trappen, S., Vandecandelaere, I., Mergaert, J. \& Swings, J. (2004). Flavobacterium degerlachei sp. nov., Flavobacterium frigoris sp. nov. and Flavobacterium micromati sp. nov., novel psychrophilic bacteria isolated from microbial mats in Antarctic lakes. Int J Syst Evol Microbiol 54, 85-92.

Versalovic, J., Koeuth, T. \& Lupski, J. R. (1991). Distribution of repetitive DNA sequences in eubacteria and application to fingerprinting of bacterial genomes. Nucleic Acids Res 19, 6823-6831.

Versalovic, J., Schneider, M., de Bruijn, F. J. \& Lupski, J. R. (1994). Genomic fingerprinting of bacteria using repetitive sequence-based polymerase chain reaction. Methods Mol Cell Biol 5, 25-40.

Wayne, L. G., Brenner, D. J., Colwell, R. R. \& 9 other authors (1987). International Committee on Systematic Bacteriology. Report of the ad hoc committee on reconciliation of approaches to bacterial systematics. Int J Syst Bacteriol 37, 463-464.

Zhu, F., Wang, S. \& Zhou, P. (2003). Flavobacterium xinjiangense sp. nov. and Flavobacterium omnivorum sp. nov., novel psychrophiles from the China No. 1 glacier. Int J Syst Evol Microbiol 53, 853-857. 